Brother, Black Sheep, or Bastard?

Situating the Tokyo War Crimes Trial in the Nuremberg

Legacy, 1946-1948

James Burnham Sedgwick

The International Military Tribunal for the Far East (IMTFE), 1946-1948 - more commonly known as the Tokyo War Crimes Trial or the Tokyo Trial-shares a kinship with the Nuremberg Trial. Together these trials attempted to establish a legal framework to end future wars. To ensure the continuity of this legacy, Tokyo borrowed much from Nuremberg. Tokyo nevertheless struggled to assert itself as more than a simple rehashing of Nuremberg tenets in a Japanese milieu. This identity crisis has had a lasting impact. Was Tokyo a co-genitor of legal precedent or merely a subordinate "next" step in judicial evolution? Should Tokyo's legal interpretations be seen as corruptions of Nuremberg statutes or necessary adaptations? What is the conjoined Tokyo-Nuremberg legacy? Japan's failure to accept responsibility for wartime actions is often seen as symptomatic of the failures of the Tokyo Trial. Conversely, German acceptance of war guilt is championed as one of Nuremberg's great successes. This paper attempts to explain these incongruities by situating the Tokyo proceedings in the Nuremberg legacy. The title question provides a useful framework for examination. This paper demonstrates that Tokyo was in parts Nuremberg's brother, black sheep, and bastard. It concludes, however, that fitting the Tokyo Trial into Nuremberg parameters ultimately worked to the detriment of both trials. Japan was not Germany; Tojo was no Hitler. Only through detailed historical examination of these mistakes can we ensure that they are not repeated by future international tribunals. Only through individual study of both trials will their joint legacy remain a positive one - no matter how flawed the original proceedings.

\title{
Brother
}

The Tokyo and Nuremberg trials were brethren in a number of ways. They had analogous origins, parallel objectives, and shared legal tenets. Because of these connections, these trials have also been subjected to similar criti- 
cisms. There is therefore some justification in labelling the IMTFE a "brother" to its German counterpart.

The origins of post-World War II international justice lay in the devastation of the war itself. As knowledge of Axis abuses spread during the war, the Allies responded with several international decrials of these violations. The Inter-Allied Joint Declaration on the Punishment for War Crimes (13 January 1942) was the first public condemnation of Axis misdeeds. ${ }^{1}$ In the "Joint Declaration", the Allies specifically declared that:

1. [A]cts of violence ... inflicted upon the civilian populations have nothing in common with the conceptions of an act of war or of a political crime as understood by civilized nations.'

2. [A]mong their principal war aims [is] the punishment, through the channel of organized justice, of those guilty of or responsible for these crimes, whether they have ordered them, perpetrated them, or participated in them.'

3. (a) Those guilty or responsible [of war crimes], whatever their nationality, are sought out, handed over to justice and judged, and (b) that the sentences pronounced are carried out.'

In other words, the Inter-Allied Declaration condemned the waging of inhumane war and declared that war criminals would be dealt with after the war. The "Joint Declaration" was therefore instrumental in the creation of both the Nuremberg and Tokyo trials. On 7 October 1942, a corollary Anglo-American Agreement was issued which promised extensive investigation of war crimes. This led to the establishment of the United Nations War Crimes Commission (UNWCC) a year later. ${ }^{3}$ On December 17 of the same year, London, Moscow, and Washington simultaneously issued a further warning that war criminals would not escape justice. ${ }^{4}$ Similarly, the Moscow Declaration of November 1943 stated that the official objective of the Allied forces was to try war criminals. The formal structure that post-

119 countries signed the Inter-Allied Joint Declaration. The conference included delegates from Australia, Belgium, Canada, China, Czechoslovakia, Free France, Great Britain, Greece, India, Luxembourg, New Zealand, Norway, Poland, the Netherlands, the Union of South Africa, the US, the USSR, and Yugoslavia. M. E. Bathurst, "The United Nations War Crimes Commission," The American Journal of International Affairs 39 (1945), 565-570.

2 Ibid., 566.

3 Ibid., 567; and Egon Schwelb, "Crimes Against Humanity," British Year Book of International Law 23 (1946), 178-226.

4 Bathurst, "The United Nations War Crimes Commission," 567-568. 
war international tribunals was not outlined, however, until the "Big Four" (France, Great Britain, the US, and the USSR) met at the London Conference in August 1945. Together these various international agreements and declarations laid the foundations for the IMTs in both Nuremberg and Tokyo.

Shared declarations of intent did not mean that Nuremberg and Tokyo had identical charters. The Nuremberg Charter was formulated at the London Conference in 1945. The Tokyo version, however, did not come until five months later and was pursuant to the Potsdam Declaration 26 July 1945-not London. ${ }^{5}$ The Tokyo Charter nevertheless borrowed much from London principles. ${ }^{6}$ This led to an unquestionable legal kinship between the Nuremberg and Tokyo trials. Like Nuremberg, the IMTFE tried its accused on similar counts. "Crimes against peace" condemned the accused of planning and carrying out of an "aggressive" war. ${ }^{7}$ A second group of charges fell under the heading of "conspiracy" to commit "murder". This conspiracy charge included killings alleged in the concurrent charge of crimes against peace. The alleged conspiracy also overlapped with a third group of charges that included conventional war crimes and "crimes against humanity". ${ }^{8}$ This "crimes against humanity" charge indicted individuals for responsibility in the wholesale slaughter, rape, enslave-

5 The Potsdam Declaration promised to uphold the terms of the Cairo Conference (1 December 1943), where Britain, China, and the US declared that they were fighting a war to "restrain and punish [emphasis added] the aggression of Japan." Potsdam furthered this objective assuring that "stern justice shall be meted out to all war criminals". IMTFE, "The Cairo Conference," Exhibits Vol. 1, Exhibit No. 1; and IMTFE, "The Potsdam Declaration," Annexes to Judgment Vol. I, Annex No. A-1, 1-4.

6 The "Tokyo Charter" used by the IMTFE changed from the one originally announced by General MacArthur in January 1946. These alterations were generally slight. In late April 1946, for example, the Charter was amended to include justices from India and the Philippines. This amendment is noted - underlined-by Justice Northcroft in his copy of the amended Charter dated 26 April 1946. See: IMTFE, "Charter of the International Military Tribunal for the Far East," Charter, Indictment, Japanese Constitution, Northcroft Collection (Christchurch, NZ: University of Canterbury). For an example of MacArthur's original declaration see: IMTFE, "Special Proclamation, Establishment of an International Military Tribunal for the Far East," Annexes to Judgment Vol. I, Annex No. A-4, 16-18. For an example of the final version of the Charter see: IMTFE, "Charter of the International Military Tribunal for the Far East,” Annexes to Judgment Vol. I, Annex No. A-5, 19-29.

7 For a contemporaneous definition of "aggression" in warfare see: IMTFE, "Convention Defining Aggression,” Exhibits, Vol. 51, Exhibit No. 2329.

8 IMTFE, "Charter of the International Military Tribunal for the Far East," Annexes to Judgment Vol. I, Annex No. A-5, 21. 
ment, murder, or otherwise brutalisation of civilians during the war. ${ }^{9}$ Conventional war crimes included violations of the customs of war, particularly abuses against POWs. In Nuremberg "crimes against peace", "conspiracy", "crimes against humanity", and conventional war crimes were represented as four individual counts of the Indictment. In Tokyo, these four allegations were grouped together in three general charges, ${ }^{10}$ which were further subdivided in 55 specific counts of war crimes. ${ }^{11}$ Tokyo's legal structure was therefore similar but not identical to its German counterpart. Shared origins and legal tenets, however, meant that Tokyo and Nuremberg were much akin in their originating forms.

There is much debate regarding whether or not Nuremberg was without legal precedent. ${ }^{12}$ Because Tokyo attempted to implement Nuremberg's precedents it has attracted similar controversy. This debate mostly surrounds the criminal counts alleged by both trials. As mentioned, both trials indicted the accused for "Common plan or conspiracy", "Crimes against peace", "War crimes", and "Crimes against humanity". Providing, of course, that a link could be made between individual accused and the ordering or commission of such crimes, few have criticised the basis of charges of conventional "war crimes". ${ }^{13}$ The charges of "crimes against peace" and "crimes against humanity", on the other hand, have received

9 IMTFE, "Charter of the International Military Tribunal for the Far East," Annexes to Judgment Vol. I, Annex No. A-5, 21-22.

10 "Crimes against humanity" and conventional war crimes were joined together in the Tokyo Indictment's third general charge.

11 IMTFE, "Indictment," Annexes to Judgment Vol. I, Annex No. A-6, 29-131.

12 This paper does not attempt to judge the merit of calling Nuremberg and Tokyo "precedent-less". Regardless of the conclusions made, this matter and the other legal issues outlined below were-and continue to be-the center of debate.

13 Justices B. V. A Röling (the Netherlands) and Henri Bernard (France) both expressed concerns that individual accused were not actually linked to crimes in Tokyo. Röling maintained, for example, that the evidence had not linked the accused to either crimes against humanity or conventional war crimes. Röling, "Some Points of Law," in Henri Bernard and B.V.A. Röling, Bernard and Röling on Judgment, Northcroft Collection (Christchurch, NZ: University of Canterbury), 13-14. Bernard, on the other hand, argued that "there can be no doubt" of the guilt of the Defendants concerning these charges, but suggested that lack of direct perpetration of the crimes should mitigate some sentences. Henri Bernard, "Dissenting Judgment of the Member from France of the International Military Tribunal for the Far East," (12 November 1948), Northcroft Collection (Christchurch, NZ: University of Canterbury), 12-16. 
extensive debate since their inception. ${ }^{14}$ The most common criticism mounted on these charges is that they constitute ex post facto legislation. ${ }^{15}$ Like Nuremberg, Tokyo has also been labelled "victors' justice"; an elaborate tool for simple vengeance. The clearest example of this is Richard Minear's, Victors' Justice: The Tokyo War Crimes Trial, a book regarded by many as the seminal work on the subject. ${ }^{16}$ Others contend that Tokyo, like its counterpart in Germany, was merely a vehicle of power politics. In 1949, for example, K. K. Basu concluded an article in the Indian Law Review writing: "With all the legal subtleties argued before it, with all the verisimilitudes of trial at law, there was nothing judicial about the Tokio [sic] tribunal. It remained throughout a mere 'manifestation of power'."17 The legal kinship the IMTFE shared with Nuremberg law therefore made it vulnerable to similar criticism.

Nuremberg and Tokyo shared common objectives as well as kindred origins and legal foundations. In his introductory remarks to the IMT Nuremberg on 20 November 1945, President of the Tribunal Lord Justice Geoffrey Laurence avowed that:

The Trial which is now about to begin is unique in the history of the jurisprudence of the world and it is of supreme importance to millions of people all over the globe. For these reasons, there is laid upon everybody who takes any part in this Trial a solemn responsibility to dis-

14 For one of the best contemporaneous discussions on the contentiousness of “crimes against humanity” see Schwelb's work. He describes the three most controversial points: First, the phraseology of the charge contained penal sanctions against individuals in a time of peace as well as at war. Secondly, the application of the charge against any civilian population "implies that civilian populations are protected against violations of international criminal law also in cases where the alleged crimes have been committed by sovereign states against their own subjects." Finally, the stipulation that "crimes against humanity" were applicable whether the domestic law of the country had been violated or not appeared in his mind "to establish the absolute supremacy of international law over municipal law." Schwelb, “Crimes Against Humanity," 178-179.

15 In other words, whether or not the trials applied new laws retroactively to the accused and held them accountable for committing crimes that were legal at the time of commission. K. K. Basu, “Tokio Trials," Indian Law Review 3 (1949), 2528; Gordon Ireland, "Ex Post Facto From Rome to Tokyo," Temple Law Quarterly 21 (July 1947), 27-49; and Gordon Ireland, "Uncommon Law in Martial Tokyo," The Year Book of World Affairs 4 (1950), 54-104.

16 Richard H. Minear, Victors' Justice: The Tokyo War Crimes Trial (Princeton, NJ: Princeton University Press, 1972).

17 Basu, "Tokio Trials," 30. 
charge their duties without fear or favor, in accordance with the sacred principles of law and justice. ${ }^{18}$

These words make it clear from the start that Nuremberg participants were acutely aware of their place in history. This sense of destiny was equally apparent in Tokyo. Even when questioning the trial's jurisdiction, Defence counsel Ben Blakeney admitted that "The responsibility before history of this Tribunal and of us who play our several parts here is tremendous, aweinspiring." ${ }^{19}$ Likewise, International Prosecution Section (IPS) member Christmas Humphreys wrote in his Japan memoirs that "even the hardboiled lawyers realised that this, whatever else it was, was history." 20

Grounded in this deep awareness of the importance of their work, participants at both Nuremberg and Tokyo sought to formulate precedents for future international tribunals. In Tokyo, the IMTFE was seen as a progressive step in the evolution of international law initiated at Nuremberg. Unsurprisingly, the prosecution and justices involved were among the foremost champions of Tokyo's role in writing legal history. Steeped in "natural law" doctrine, but seeking positivist outcomes, Chief Prosecutor Joseph B. Keenan and fellow IPS member Brendan F. Brown called Nuremberg and Tokyo, "the original cells from which a fully developed specimen of international criminal law will evolve." ${ }^{21}$ Daniel Sutton, a col-

18 Nuremberg Trial Proceedings Vol. 2, The Avalon Project at Yale Law School. http:// www.yale.edu/lawweb/avalon/imt/proc/11-20-45.htm (accessed 9 September 2006).

19 Ben Bruce Blakeney, "International Military Tribunal: Argument for Motions to Dismiss," The American Bar Association Journal 32 (1946), 523. See also: Brendan F. Brown, "Red China, the Tokyo Trials, and Aggressive War," Louisiana Bar Journal 3 (January 1956), 145; Solis Horwitz, “The Tokyo Trial,” International Conciliation 465 (November 1950), 475 and 542; Christmas Humphreys, Via Tokyo (London: Hutchinson \& Co. (Publishers) Ltd., 1948), 83; Delfin Jaranilla, “Concurring Opinion: By the Honorable Mr. Justice Delfin Jaranilla Member from the Republic of the Philippines," (1 November 1948), Northcroft Collection, 4-5; and B. V. A. Röling, "Opinion of Mr. Justice Röling, Member for the Netherlands," (12 November 1948), 1 and 51.

20 Humphreys, Via Tokyo, 83.

21 Joseph B. Keenan and Brendan F. Brown, Crimes Against International Law (Washington: Public Affairs Press, 1950), 160. See also: Horwitz, "The Tokyo Trial," 541; A. Frederick Mignone, "After Nuremberg, Tokyo," Texas Law Review 25 (1946-1947), 475-478; R. Quentin Quentin-Baxter "The Task of the International Military Tribunal at Tokyo," New Zealand Law Journal 25 (7 June 1949), 133-134 and 137; and Ronald H. Quilliam, "'Report on the Proceedings of the International Military Tribunal for the Far East', Letter to the Prime Minister of New Zealand," (29 January 1948), Northcroft Collection, 16. 
league of both Keenan and Brown, later wrote that the IMTFE was "one of the first steps, but a long and upward step, taken to replace a system of force with a system of law and order." 22 Members of the Tribunal were equally effusive on this point. New Zealand IMTFE Justice Erima H. Northcroft declared that "The substantial purpose of the trials at Nuremberg and at Tokyo will have been achieved if a code of international law emerges." ${ }^{23}$ Despite being widely held as a critic of the IMTFE, Dutch Justice B. V. A. Röling also extolled its role in a new era of conflict resolution, saying: "I am still convinced that the Trial was a kind of milestone in legal development, and the attitude on which the judgements were based is absolutely necessary in the atomic era." 24 After the war, many felt that a new enforcement regime was needed for war crimes. Together, participants at Nuremberg and Tokyo set out to codify and establish the international criminal law necessary to achieve these ends.

Along with kindred beliefs in their roles in the history and the evolution of law, participants at both Tokyo and Nuremberg sought to deter individuals and nations from future wars of aggression. Justice Robert $\mathrm{H}$. Jackson, US Prosecutor in Nuremberg reported to President Truman in October 1946 that,

The four nations through their prosecutors and through their representatives on the Tribunal, have enunciated standards of conduct which bring new hope to men of good will and from which future statesmen will not lightly depart. These standards by which the Germans have been condemned will become the condemnation of any nation that is faithless to them..$^{25}$

22 Daniel N. Sutton, "The Trial of Tojo: The Most Important Trial in All History?" American Bar Association Journal 36 (February 1950), 165.

23 Erima H. Northcroft, "Document 728: 'The New Zealand Member, International Military Tribunal for the Far East to the Deputy Secretary of External Affairs', Tokyo, 20 April 1948 (Received 30 April)," PM 106/3/22, Documents on New Zealand External Relations, Volume II: The Surrender and Occupation of Japan, ed. Robin Kay (Wellington, NZ: P. D. Hasselberg, Government Printer, 1982), 1718. See also Erima H. Northcroft, "Memorandum for the Right Honourable the Prime Minister Upon the Tokyo Trials 1946-1948, By the Honourable Mr. Justice Northcroft," (17 March 1949), Northcroft Collection, 2.

24 B. V. A. Röling and Antonio Cassese (ed.), The Tokyo Trial and Beyond: Reflections of a Peacemonger (Cambridge, UK: Polity Press, 1993), 86.

25 "Report of Robert H. Jackson, United States Representative to the International Conference on Military Trials: London, 1945," (7 October 1946), The Avalon Project at Yale Law School. http://www.yale.edu/lawweb/avalon/imt/jackson/jack 63.htm (accessed 9 September 2006). 
In his publication with Brendan Brown, Tokyo Chief Counsel Joseph Keenan echoed his Nuremberg counterpart's sentiments averring that, "this trial will probably deter many future leaders from resorting to crimes against international law." 26 Justice Northcroft concurred, concluding that the combined efforts of Nuremberg and Tokyo had validated the idea of holding individuals accountable for the actions of a state. He continued that, "In this way a warning has been given to national leaders who contemplate aggression." 27 Others were sceptical that Tokyo would actually have a preventative effect, but were nevertheless convinced that this should be one of its objectives. Frederick Mignone (IPS), for example, wrote that "the world needs all the preventative protection possible against the rise of new leaders willing to gamble anew the lives of millions of helpless subjects." ${ }^{28}$ Justice Röling agreed saying simply: "The dreadfulness of World War II . . . made us realize the necessity of preventing wars in the future." 29

The close connection between Nuremberg and Tokyo therefore manifested itself in a number of ways. Both originated in similar Allied declarations and conferences promising the punishment of Axis war criminals. As a result, both trials shared a number of legal tenets. In fact, it was hoped that Tokyo would become the first trial to substantiate the Nuremberg charges of international "conspiracy", "crimes and against peace", and "crimes against humanity". Similar law led to a shared burden of legal criticism furthering the sense of kinship between the trials. Finally, as the first steps taken towards codifying international criminal law, both the IMTFE and IMT Nuremberg shared the common objective of deterring future aggression. It therefore becomes apparent upon review that, on certain levels at least, the IMTFE was indeed a "brother" to its German precursor.

\section{Black Sheep}

There was-and is - no way to deny the kinship these trials shared. But if the Tokyo Trial is recognised as a brother to Nuremberg, it must also be acknowledged that it was, at best, the black sheep of the family. Nuremberg is often painted as the originator of international criminal justice. The validity of its judicial model is debated, but its importance as a pioneer is

26 Keenan and Brown, Crimes Against International Law, 160.

27 Northcroft, "Memorandum”, 11.

28 Mignone, "After Nuremberg, Tokyo," 490. See also: Sutton, “The Trial of Tojo," 165.

29 Röling, “Opinion,” 45. 
unquestioned. The work of Tokyo jurists, on the other hand, is rarely acknowledged let alone commended. Participants in Tokyo were uncomfortable with its billing as Nuremberg's "little Brother" from the start. Indeed, during his introductory remarks to the court, IMTFE President Sir William Flood Webb declared that "There has been no more important trial in history." 30 Webb's assertion aside, Tokyo became the embarrassing and near-forgotten scion of the Nuremberg family tree. This is not to say that the IMTFE has been completely ignored. Compared to Nuremberg, however, it remains banished to the periphery of media, academic, judicial, and international consciousness; an historical afterthought.

This mantra of historical neglect may seem pat but there is undeniable truth to it. To verify this assertion one need not stray farther afield than a good local library. Any search for the Nuremberg proceedings will be met with a veritable stack of books from the likes of Michael R. Marrus, Richard Overy, Bradley F. Smith, Telford Taylor, Ann and John Tusa, and Robert K. Woetzel to name but a few. ${ }^{31}$ A similar query for the Tokyo Trial will yield notably less. It is not likely that more than a handful of books will be available. Moreover, the works that are common are generally out of date and unsatisfactory. The three most likely search results are Richard Minear's, Victors' Justice, Philip Piccigallo's The Japanese on Trial: Allied War Crimes Operations in the East, 1945-1951,32 and Tim Maga's Judgment at Tokyo: The Japanese War Crimes Trials. ${ }^{33}$ Although admirable, Minear's selflabelled "polemical" work is now over thirty years old and outmoded. Piccigallo's work has also been in publication for nearly thirty years. Furthermore, the IMTFE is only part of his much larger account of all trials of Japanese war criminals in Asia. Finally, despite its misleading title, Maga's work uses only 35 of its total 181 pages to cover the IMTFE. The current IMTFE historiography therefore leaves much to be desired.

30 IMTFE, Transcripts of Proceedings (3 May 1946), 1.

31 Michael R. Marrus, The Nuremberg War Crimes Trial, 1945-1946: A Documentary History (Boston: Bedford Books, 1997); Richard Overy, Interrogations: The Nazi Elite in Allied Hands, 1945 (New York: Viking Penguin, 2001); Bradley F. Smith, Reaching Judgment at Nuremberg (New York: Basic Books, Inc, Publishers, 1977); Telford Taylor, The Anatomy of the Nuremberg Trials: A Personal Memoir (New York: Alfred A Knopf, 1992); Ann Tusa and John Tusa, The Nuremberg Trial (New York: Atheneum, 1984); and Robert K. Woetzel, The Nuremberg Trials in International Law (New York: Frederick A. Praeger, Inc., 1960).

32 Philip R. Piccigallo, The Japanese on Trial: Allied War Crimes Operations in the East, 1945-1951 (Austin, TX: University of Texas Press, 1979).

33 Timothy P. Maga, Judgment at Tokyo: The Japanese War Crimes Trials (Lexington, KY: University Press of Kentucky, 2001). 
Whether or not this disproportion existed during the trials' proceedings is less clear. An analysis of Japanese media coverage of the IMTFE completed by US occupation authorities in September 1946 concluded that "Contrary to expectation, the trial of 28 Japanese citizens, singled out by the Allied Powers for prosecution on war guilt charges, has not been a leading topic for comment in the nation's periodicals." ${ }^{4}$ The quantity of contemporary trial coverage in the West reveals a similar level of indifference. Generally, the amount of discussion garnered by German trials in contemporary media and academic writings far outstripped that of Japanese proceedings. Between 1945 and 1951, for example, 26 law journals published 36 articles concerning Japanese war crimes trials. Over the same period, 69 articles about German trials were printed in 38 legal journals. The New York Times and the Washington Post demonstrate a comparable disparity in popular media coverage. Between August 1945 and May 1951-the period of Allied war crimes operations-the New York Times carried 145 articles about Japanese trials. Over the same period, it printed 246 articles on German trials. This disproportion was even greater in the Washington Post, where between the same dates it printed more than twice as many (146) articles on Germans trials than it did on those on the Japanese (71). "Figure 1: Comparison of New York Times Coverage of Japanese and German War Trials, August 1945 - December 1948” reveals that coverage of German trials remained pre-eminent even over a period dominated by Japanese trials. The majority of these articles focused on the IMTs in Tokyo and Nuremberg. The disproportion between January 1947 and October 1948 is especially noteworthy since this period came long after the end of the Nuremberg Trial. Even when Tokyo was the only "major" war crimes trial underway, it was outstripped by coverage of "minor" German trials. ${ }^{35}$

34 Media Analysis Division, Civil Information and Education Section, Supreme Commander for the Allied Powers (SCAP), "Publication Analysis," (11 September 1946), (Christchurch, NZ: Harold J. Evans Papers, private collection).

35 For more on contemporary media, academic, and internal views on the Tokyo Trial see: James Burnham Sedgwick, "Western Reaction to Allied War Crimes Operations in the Far East, 1945-1951: Apathetic and Insignificant?” MA Thesis (Christchurch, NZ: University of Canterbury, 2004). 
Figure 1:

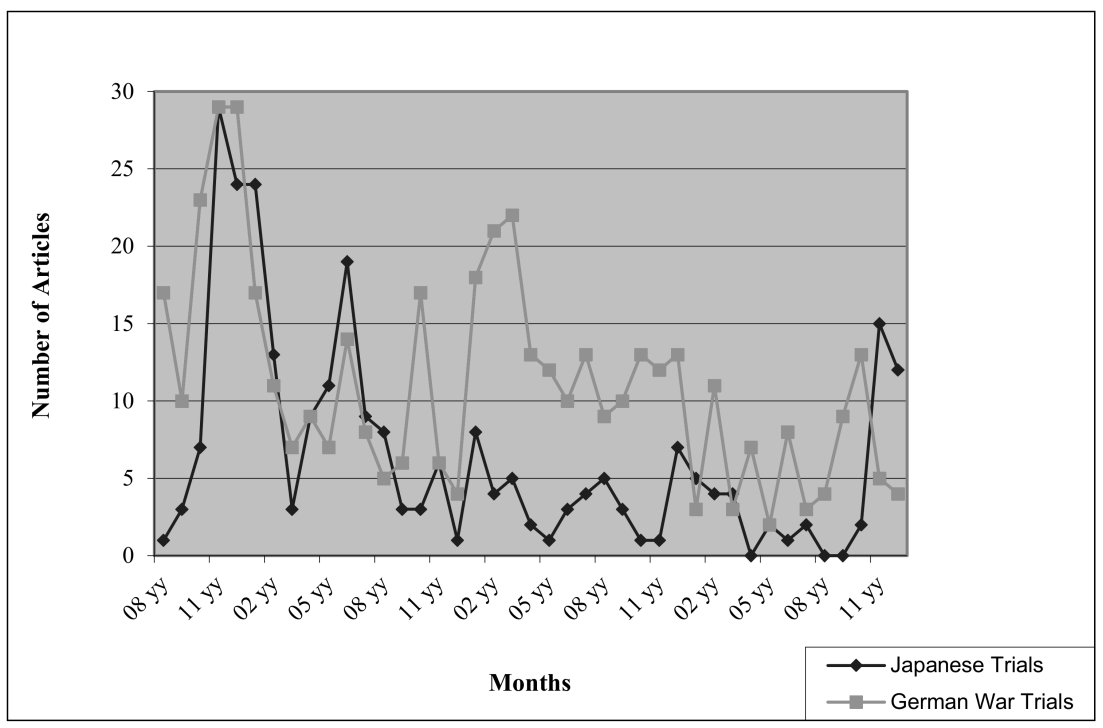

Comparison of New York Times Coverage of Japanese and German War Trials, August 1945-December 1948

These results support the contention that Tokyo remained the forgotten son of international justice for the majority of its proceedings. The trial itself is not all to blame for this lack of attention. In many ways, its black sheep status lay in the global climate of the era. Perhaps the most readily perceivable reason that knowledge of Tokyo beggared in comparison to that of Nuremberg was timing. Simply put, Nuremberg came first, striking while the iron was hot and effectively making Tokyo the "first" loser. Similarly, for a trial of its magnitude, the Nuremberg Trial was relatively brief (11 months long). Tokyo overstayed its welcome in the public eye taking over two and half years. It is also possible that the public was numbed into apathy after several years of revelations about horrendous crimes. Geography undoubtedly played a significant role. Nuremberg was both more accessible to journalists and more interesting to the Western public. People in the West had little familiarity with the alien, difficult to remember names of Japanese "villains". The Nazi accused, on the other hand, largely represented the bogeymen of wartime society in the West. Daily coverage was just too difficult in Tokyo; and not required. Additionally, other than the most gruesome testimonies, much of Tokyo's time was spent on legal issues. Although of note to scholars, these did not have wide public appeal. 
Of course, Nuremberg involved legal matters as well, but these were generally less disputed than Tokyo's. Finally, other momentous events in Asia detracted from Tokyo coverage but had limited impact on Nuremberg. These included de-colonisation movements in Asia, the birth of the Atomic era, the emergence of the Cold War, and civil war in China.

International conditions were also largely responsible for dictating the tone of IMTFE coverage. The prevailingly negative quality of this coverage better reveals Tokyo's role as black sheep to Nuremberg. In short, Tokyo was a disappointment. Nuremberg was seen as an intrepid legal pioneer. Although imperfect, it had laid the foundation for future justice. As the first test case Tokyo failed under the burden of trying to squeeze the Japanese situation into the pat Nuremberg framework. Instead of reifying the German precedent, Tokyo made it more convoluted, controversial, and cumbersome. Worsening Cold War tension, especially the emerging Korean conflict, did little to appease critics. Their growing disenchantment coloured contemporary writings on Tokyo. The once optimistic proponents of a peaceful global community based on the deterrent of criminal accountability found themselves embittered when confronted by the harsh post-Tokyo reality. The Nuremberg and Tokyo Judgments were revealed as impotent just years after their pronouncement. Because it was unsuccessful in solidifying Nuremberg tenets, Tokyo was often saddled with blame for the "failure" of both trials.

IPS member Brendan Brown offers a poignant example of this disillusionment. In 1950, Brown co-authored a book with Chief Prosecutor Keenan that extolled the "new" laws of Nuremberg and Tokyo. "[T]he Tokyo and Nuernberg war crimes trials were manifestations of an intellectual and moral revolution" they wrote, a revolution, "which will have a profound and far reaching influence upon the future of world society." 36 Only six years later, a disaffected Brown lamented that, "If all truth is relative and subjective, then all law, including international law, is in essence power, and aggressive war is whatever those who have the power choose to declare it to be at any particular time." 37 Written in reaction to the failure of IMTFE nations to enact their precedent against Chinese and Soviet aggression in Korea, Brown's words help explain why Tokyo has slipped into relative anonymity and why coverage of the trial tended to be negative.

Criticism of the Tokyo proceedings was not unique to this post-trial period. Jessica C. E. Gienow-Hecht's “Trial by Fire: Newspaper Coverage of

36 Keenan and Brown, Crimes Against International Law, v-vi.

37 Brown, "Red China," 153. 
the Nuremberg Proceedings" argues that press coverage of the Nuremberg Trial was censored to project a positive image of the trial to the German public. This was done to suit the overall aim of occupying forces to use the IMT as a tool for "re-education". ${ }^{38}$ Despite similar efforts by General MacArthur to control the tone of media coverage of the Tokyo Trial, its public image remained largely negative. Time Magazine, for example, called Tokyo, "a third-string road company of the Nurnberg [sic] show . . . [where] The German production had a touch of Wagner . . . Tokyo's had the flavour of Gilbert \& Sullivan." ${ }^{39}$ Similarly, The Press [Christchurch, NZ] regretted the "doleful knowledge" that the IMTFE continued to "drag on" even after 15 months, and concluded that "unlike their fellow war criminals in Germany, who died at least in a blaze of publicity, the Tokyo 25 will die unremembered, even by many of their own countrymen." 40 Academics were also critical. In The Year Book of World Affairs, Gordon Ireland denounced the IMTFE as "not an example of international law at all but no more than a round-about subterfuge by which victorious nations through legal forms avenged themselves on enemy leaders who committed the real crime of being beaten." ${ }^{41}$ Few contemporaries denied the kinship between Tokyo and Nuremberg, but acknowledgement of this bond became increasingly begrudging. By the end the disappointment embodied in Tokyo left it studiously ignored by the press, scholars, and the public at the time and in the decades since. The way that it inspired a combination of embarrassment and disregard in observers casts the Tokyo Trial as the black sheep of Nuremberg's family.

\section{Bastard}

Tokyo's black sheep persona stems mostly from its treatment of the legacy it inherited from Nuremberg. The IMTFE was undoubtedly founded with lofty ideals. As mentioned, its organisers sought to join Nuremberg in establishing a legal framework to end future wars of "aggression”. Rather

38 Jessica C. E. Gienow-Hecht, "Trial by Fire: Newspaper Coverage of the Nuremberg Proceedings," Studies in Newspaper and Periodical History: 1995 Annual, eds. Michael Harris and Tom O’Malley (Westport, CT: Greenwood Press, 1995), 167183.

39 "Road Show," Time Magazine 47 (20 May 1946), 24.

40 "Trial of Japan's Leaders: Tribunal Resumes after Recess: 'Almost Forgotten By the World'," The Press (6 August 1947), 7.

41 Ireland, "Uncommon Law", 87-88. 
than reinforcing Nuremberg precepts, however, jurists at Tokyo were forced to reconfigure them. Tokyo's failure to apply "pure" Nuremberg precedent encouraged contemporaries to label it a black sheep. In retrospect, the adaptations made by Tokyo participants also brand the trial as a "bastard" form of Nuremberg law. Tokyo began with parallel origins, kindred objectives, and near-identical law to its German counterpart. By the end, it had taken these commonalities and created an almost unrecognisable entity. In many ways, Tokyo would have been better off establishing its own framework from the beginning. Because it did not, however, it will remain Nuremberg's bastard.

The most fundamental issues were legal. Trying to apply the Nuremberg conventions of "conspiracy", "common plan", and "aggression" in the Japanese setting revealed unforeseen weaknesses in the law. These charges were tailor made for Germany. There was a clear group-the Nazis—with a clear leader-Hitler-that had taken clearly aggressive steps to initiate and precipitate war. In Japan, however, the situation was far more complex. Japan had 17 Cabinets and 16 Prime Ministers in the period investigated by the IMTFE (1927-1945).42 If there was one continuous "leader" it was Emperor Hirohito. Debate continues, however, over the extent to which the Emperor operated as a mere figurehead or played an active role in Japan's "aggression”. Regardless, he was certainly no Hitler. Furthermore, this already varying number of governments was almost infinitesimally segmented by internal schisms, secret societies, and interest groups. Prosecutors in Tokyo therefore had difficulty sustaining the argument that pre-war Japan's movement towards war was the result of a clear conspiracy and common plan. Despite the inherent probative challenges, the IPS persisted in mirroring Nuremberg charges in Tokyo. This stubborn adherence to Nuremberg precepts opened Tokyo up to criticism that discredited the work of both IMTs.

Things were further complicated by trying to apply the Nuremberg definition of "aggression" to the Japanese context. The Nuremberg Indictment placed the beginning of the "common plan" with the founding of the Nazi Party in 1920, and the start of "aggression" with the invasion of Austria in March 1938. The exact start of war in Asia is more difficult to define. Many Western, particularly American, scholars contend that the struggle did not become a global one until the attack on Pearl Harbor and the invasion of

42 Prince Konoe Fumimaro was Prime Minister for two non-consecutive terms. He committed suicide after the war and was therefore never brought to trial. 
other Western settlements in Asia in December $1941 .{ }^{43}$ Others point to the Japanese invasion of China in 1937,44 and still others suggest that a "Great Asian War", also known as the "15 Year War", began with the Japanese envelopment of Manchuria in late 1931..$^{45}$ The IMTFE, for its part, alleged that a Japanese conspiracy to wage war dated as far back as 1927 with the so-called "Tanaka Memorial" 46 and the assassination of the Manchurian warlord Zhang Zuolin (Chang Tso-Lin). Tokyo therefore faced far greater difficulty than its German counterpart in proving a precise flashpoint of Japanese "aggression". The challenge of tying this together in a "conspiracy" to wage a "war of aggression" has led to criticism of the Tokyo Indictment and its creators.

Complicating matters even further is the debateable neutrality of the Allied "victims" of Japanese aggression. Justices Henri Bernard (France), Radhabinod Pal (India), and B. V. A. Röling (the Netherlands), for example, saw the rise of communism in China as a legitimate threat to Japanese possessions on the continent. Although not an absolution of Japanese guilt,

43 Basil Collier, The War in the Far East, 1941-1945: A Military History (London: William Heinemann Ltd., 1969); John Costello, The Pacific War, 1941-1945 (London: William Collins Sons and Co. Ltd., 1981); and John J. Sbrega, The War Against Japan, 1941-1945: An Annotated Bibliography (New York and London: Garland Publishing, Inc., 1989).

44 John Hunter Boyle, China and Japan at War, 1937-1945: The Politics of Collaboration (Stanford, CA: Stanford University Press, 1972); James C. Hsiung and Steven I. Levine (eds.), China's Bitter Victory: The War with Japan, 1937-1945 (Armonk, NY: M. E. Sharpe, 1992); Hsu Long-hsuen and Chang Ming-kai, History of the Sino-Japanese War (1937-1945), Wen Ha-hsiung (trans.) (Taipei: Chung Wu Publishing Co., 1972); Hu Pu-yu, A Brief History of the Sino-Japanese War (1937-1945) (Taipei: Chung Wu Publishing Co., 1974); and Dick Wilson, When Tigers Fight: The Story of the Sino-Japanese War, 1937-1945 (New York: Viking Press, 1982).

45 Peter Duus, Ramon H. Myers, and Mark R. Peattie (eds.), The Japanese Wartime Empire, 1931-1945 (Princeton, NJ: Princeton University Press, 1996); Saburo Ienaga, The Pacific War: World War II and the Japanese, 1931-1945 (New York: Pantheon Books, 1978); and The Sino-Japanese Conflict 1931-1941: Prelude to Pearl Harbor Volumes 1-5 (Nedeln, Liechtenstein: Kraus Reprint, 1980).

46 The "Tanaka Memorial" was a directive purportedly presented to Emperor Hirohito on 25 July 1927 by Japanese Premier Baron Tanaka Giichi advocating Japanese occupation of Northeast China, and eventually the entire Chinese nation. It has since been proven a forgery. Gavan McCormack, Chang Tso-lin in Northeast China, 1911-1928: China, Japan, and the Manchurian Idea (Folkestone, Kent: William Dawson \& Sons Ltd., 1977), 236. Interestingly, although the IMTFE Prosecution pinpointed the "Tanaka Memorial" (1927) as the beginning of Japanese aggression, it began its Indictment in January 1928. 
they felt that this negated accusations of "aggression". ${ }^{47}$ In fact, Justice Pal contended that US aid to China before 1941 could be considered an act of aggression against Japan. In the very least, Pal asserted that this obviated Japanese "aggression" at Pearl Harbor. ${ }^{48}$ Similar arguments existed concerning the Allied economic blockade imposed on Japan in the late 1930s. ${ }^{49}$ Furthermore, the inclusion of a Soviet member at the IMTFE proved an awkward matter. Once there, the Soviet team forced allegations of Japanese aggression against Russian troops into the Indictment. This was a tenuous contention given the fact that the USSR had not officially declared war on Japan until after its effectual surrender. Including Soviet representatives was a political necessity but members of the Defence, the Prosecution and the Bench found this inclusion embarrassing. ${ }^{50}$ Moreover, these allegations undermined attempts by the Prosecution in Tokyo to reinforce a Nuremberg view of "aggression".

The ideals of Nuremberg were not inappropriate. In fact, they could readily be accepted as positive steps in international conflict resolution. The Tokyo Trial was therefore undoubtedly well-intentioned in trying to reinforce and expand Nuremberg ideals. It was to the detriment of both trials, however, to try to fit Tokyo into Nuremberg parameters. The IMTFE would therefore have been better off creating entirely new precepts designed specifically for a situation that differed significantly from the Germany one. In fact, Tokyo's best successes came in the areas where it showed the most independence and initiative in defining itself.

This is apparent in how Tokyo confronted its linguistic challenges. Four languages-English, French, German, and Russian-were used in Nurem-

47 Henri Bernard, "Remarks Concerning the Draft of Judgment of the Majority [Concerning Part B Chapter V, Vol. I]," (2 July 1948), Bernard and Röling on Judgment, 1-20; Radhabinod Pal (India), "International Military Tribunal for the Far East: Judgment of the Honourable Mr. Justice Pal, Member from India,” (30 July 1948), 254-257 and 312-314; and B. V. A Röling, "Judgment Part B, Chapter III: 'Japanese Aggression against the USSR'," (28 July 1948), Bernard and Röling on Judgment, 6-7.

48 Pal, "International Military Tribunal for the Far East," 261-262 and 1022-1024.

49 See for example: Röling, "Judgment Part B, Chapter III," 27 and 30-31.

50 Bernard, "Dissenting Judgment," 11; Ben Bruce Blakeney, "International Military Tribunal: Argument for Motions to Dismiss," The American Bar Association Journal 32 (1946), 476; George F. Blewett, "Victor's Injustice: The Tokyo War Crimes Trial," American Perspective (Summer 1950), 287-288; Pal, "International Military Tribunal for the Far East," 241-246; and Carrington Williams, "The Tokyo War Crimes Trial before the International Military Tribunal for the Far East," International Humanitarian Law: Origins, eds. John Carey, William V. Dunlap, and R. John Pritchard (Ardsley, NY: Transnational Publishers, 2002), 121-122. 
berg. Interpreters for these languages were readily available, and thus translation services were relatively straightforward and rapid. The logistics of the Japanese situation, on the other hand, forced Tokyo organisers to bastardise the Nuremberg approach. In Tokyo, there were officially only two languages; English and Japanese. These two alone presented difficulties because of inherent differences between the two languages. There was also a deficiency of professional translators in the field. On top of this, the trial saw testimony in numerous other languages. This presented a situation where Nuremberg procedure could offer no help to its Japanese brother. The Tokyo Trial eventually surmounted these translation issues but not before they greatly prolonged its proceedings. These administrative issues demonstrate that not all the forced adaptations made to the Nuremberg model in Tokyo had negative results. Indeed, in this case, the resulting adjustments may well be one of Tokyo's greatest legacies. The lessons learned from such a huge project have yet to be satisfactorily investigated. When this is done, however, it is likely that the Tokyo approach to language issues will prove more relevant to modern international criminal law than those legitimated in Nuremberg.

Tokyo was also groundbreaking as an example of international cooperation not seen in Nuremberg. In this area Tokyo was again confronted with a situation about which Nuremberg could offer little guidance. The German trial was the work of four major powers. Relations between these countries were not "simple" but interaction was based on accepted bigpower diplomacy. Tokyo was also dominated by major powers. Indeed, many experts contend that it was a wholly American trial. ${ }^{51}$ It was more than that, however. In total, eleven nations of varying international status participated in the IMTFE. Major powers such as China, France, Great Britain, the USSR, and the US all played significant roles. So too did less powerful countries such as Australia, Canada, and New Zealand, and the Netherlands. Moreover, two nations not yet officially formed-India and

51 There is much debate about the extent to which the IMTFE was dominated by the US. In July 1946, New Zealand Justice Northcroft, for example, complained to the New Zealand Department of External Affairs that "the whole thing is an American 'show"'. Erima H. Northcroft, "Document 681: 'The New Zealand Member, International Military Tribunal for the Far East to the Secretary of External Affairs', Tokyo, 2 July 1946," PM 59/2/49, Documents on New Zealand External Relations, Volume II: The Surrender and Occupation of Japan, 1613. More recently, historian Donald Cameron Watt has argued that American predomination was an expected necessity. Donald Cameron Watt, "Historical Introduction," The Tokyo War Crimes Trial: Index and Guide, Vol. I, eds. R. John Pritchard and Sonia Magbanua Zaide (New York: Garland Publishing, 1987), vii-xxiii. 
the Philippines-were represented with both justices and prosecutors. Burma was similarly given standing with a prosecutor. The adjustments made in Tokyo to accommodate its greater international diversity may help label Tokyo a bastard to the Nuremberg processes. On the other hand, these changes also represent some of the trial's greatest accomplishments.

The Tokyo Trial was an international military tribunal in a way that defies labelling as a simple replication of Nuremberg. The greater complexity of international relations meant that Tokyo experienced internal challenges that Nuremberg precedent had no answer for. Developing Cold War tensions created a rift between Soviet and other representatives. These tensions existed in Nuremberg, but by the time the IMTFE began Cold War politics had become the diktat of international diplomacy. There was also significant resentment between British Commonwealth representatives and the Americans. A more significant divide existed between the English speaking countries - which dominated numerically-and other nations. The extent that "lesser" powers were able to impact the trial is also debated. The fact is, however, that they were there, and they were included. Moreover, the President of the Tribunal was an Australian; not an American, Briton, Frenchman, or Russian. Nuremberg may prove a sound instructive example for future European tribunals, but Tokyo represents the first true example of a global one. The interplay, successes, and failures of running this truly international organisation have received scant attention. This is unfortunate, because these may prove to be the most lasting legacies of the IMTFE. Traditionally, the legacy of Nuremberg and Tokyo -when it is discussed at all-has been labelled a joint one. This paper has established, however, that Tokyo's relationship to Nuremberg was as much a divergent one as it was a shared kinship. The conjoined legacy of Nuremberg and Tokyo is revealed as confusing and unsatisfactory. It is therefore timely to turn this discussion towards how the Tokyo and Nuremberg legacies should be regarded.

\section{True (Shared?) Legacy}

This study's title poses a question: Is the Tokyo Trial best viewed as Nuremberg's brother, black sheep, or bastard? In parts at least, Tokyo was all of these. It was a "brother" in objectives and legal tenets but a "black sheep" in the eyes of contemporary academia and the media. It can also be viewed as a "bastard" to its precursor's legacy because many of Nuremberg's lessons proved untenable in the Tokyo setting. Tokyo was all of these things, yet it was more. In modern times, international war crimes 
trials are an unfortunately regular-and ongoing-occurrence. Before the end of World War II this was not the case. In fact, until the International Military Tribunal Nuremberg and its counterpart in Tokyo, there had never been an extensive international effort to try war crimes. Perhaps the most effective way for modern international tribunals to learn from the experiences of their predecessors in Nuremberg and Tokyo is to focus less on their conjoined legacy and more on how they met different challenges. Law is an evolution of concepts. If Nuremberg represents the origins, then Tokyo was its first test case. An undoubted kinship exists between these trials but together they present a convoluted and confusing foundation of law. Individually, however, they represent valuable links in an ongoing chain of international criminal jurisprudence.

Because of a relative abundance of sources, Nuremberg has been extensively researched. For the very opposite reason, the IMTFE has been underexamined to say the least. Lessons may yet be garnered from the Nuremberg model. Because of its relative anonymity, however, the Tokyo approach may have more to offer to the ongoing evolution of international criminal law. It was, after all, larger, more international, more complex, and greater in scope than its German associate. The very lack of investigation into the IMTFE demands rectification. This dearth of attention is all the more demanding - and curious-given the enormously complex and controversial nature of the IMTFE. For a large part, the fact that the trial remains controversial is due to its own mistakes. But issues of logistics and scope also make the trial study-worthy. Indeed, the list of debatable topics is nearly endless. It is my hope that papers such as this will encourage a more varied and multidisciplinary approach to the study of international criminal law, particularly in its formative stages. Together Nuremberg and Tokyo make up the earliest multilateral attempts to end impunity for war crimes. Separately, they represent potent examples of what running such trials entails. Only by treating each trial as individual objects of study can we truly hope to understand and benefit from the experiences of these pioneers of international jurisprudence. 
